\title{
ANALISIS NILAI-NILAI MULTIKULTURAL MASYARAKAT DESA PATOMAN, BLIMBINGSARI, BANYUWANGI
}

\author{
Demas Brian Wicaksono ${ }^{1}$, I Kadek Yudiana² ${ }^{2}$ Andika Wahyudiono ${ }^{3}$ \\ bimapunkrock@gmail.com, ikadekyudiana@untag-banyuwangi.ac.id, \\ wahyudion21@gmail.com \\ IImu Hukum, Fakultas Hukum, Universitas 17 Agustus 1945 Banyuwangi $^{1}$ \\ Pendidikan Sejarah, Fakultas Keguruan dan IImu Pendidikan, Univeritas 17 Agutus 1945 \\ Banyuwangi ${ }^{2}$
}

Administrasi Publik, Fakultas IImu Sosial dan Politik, Univeritas 17 agutus 1945 Banyuwangi $^{3}$

\begin{abstract}
This article attempts to analyse the cultural values that exist in the village of Patoman and how to manage the Kemultikulturan resulting in the harmony of both inter religious, ethnic, ethnic, and cultural. The method used in this study is qualitative deskriftif analysis with the steps: 1) Determination of the research site; 2) research time; 3) forms and strategies used qualitative descriptive analytic; 4) data retrieval techniques in the form of in-depth interviews, direct observation, and document studies; 5) data validation by using data triannggulation, researcher, theory, and Methodelogis; 6) While the data analysis technique uses qualitative data analysis techniques which include data collection, data reduction, data feeds, and withdrawal/verification. The results showed that the values contained in the modernation of Patoman village community include: Social value, sympathy, tolerance and empathy, religious, nationalism, Gotong Royong, democracy, friendly/communicative, love for the environment, peace and social care. In managing the Kemultikulturan in Patoman village is carried out in several ways, namely dialogue and cooperation between religious people, believing their own religion and respecting the religion of others, mutual prayer, intercultural communication, tolerance, sympathy, and empathy, the national village, the national interweaving Forum, and the inter-religious harmony Forum.
\end{abstract}

Key words: Multicultural, value, society, Patoman.

\section{PENDAHULUAN}

Kemajemukan Indonesia merupakan hal yang membanggakan namun juga berdampak pada munculnya peluang yang lebih besar terjadinya masalah (Suratman, dkk, 2013: 165). Menurut Siswomiharjo (dalam Pageh, dkk, 2013: 4), juga menjelaskan bahwa bagi Indonesia sebagai bangsa yang pluralis berkenaan dengan kesepakatan hidup bersama antar agama, etnik, dan budaya maka sering menimbulkan gejala-gejala yang mengarah pada perpecahan bangsa". Tumagor, dkk (2010: 127) juga menguraikan secara jelas mengenai potensi konflik yang dapat terjadi di Indonesia, yakni: 
“Masyarakat multikultural yang terdiri oleh kemajemukan kelompok etnik (etnic group) beserta adat budayanya itu, bukan hanya berpotensi menjadikan negara Indonesia sebagai bangsa yang tangguh di masa depan, tetapi juga menicu lahirnya konflik sosial yang bisa mengintimidasi pilar-pilar persatuan negara bangsa (nation state), jika perubahan keberagaman sosial budaya itu tidak mampu diatur dengan baik".

Meminjam istilahnya Suratman (2013: 4) mengatakan Indonesia adalah bangsa yang Multikultur/Majemuk. Dewasa ini, hal yang perlu kita melakukan ialah mencari solusi untuk mengelola kemultikulturan bangsa Indonesia. Dalam mengelola kemultikultuan cara pandang kita harus dirubah yaitu menjaga kemultikulturan tidak cuma bagian tanggung jawab dari pemerintah pusat tetapi seluruh warga negara Indonesia termasuk masyarakat pedesaan turut bertanggungjawab. Hal ini sejalan dengan pandangannya Yudiana (2017) Wicaksono (2018) yang mengatakan desa merupakan representative dari kemultikulturan Indonesia.

Desa Patoman merupakan desa dengan tingkat kemultikulturan yang tinggi. Mulai dari agama Islam dengan jumlah $82.3 \%$, Hindu mencapai $17.3 \%$, Kristen sebanyak 8 jiwa, Buddha 7 Jiwa dan kepercayaan khususnya kejawen. Dilihat dari etnik seperti Madura, Jawa, Bali, dan Osing. Dengan kemultikulturannya saat ini bukan hal yang niscaya kalau sewaktu-waktu bisa saja menimbulkan perpecahan.

Kehidupan masyarakat di Desa Patoman nampak sangat damai dan rukun walaupun di dasari oleh perbedaan agama dan suku. Hal ini tercermin dalam tata letak tempat ibadah yang dibangun secara berdekatan. Setidaknya hal tersebut menjadi indikator keharmonisan interaksi antar individu dari latar belakang agama yang berbeda. Realitas ini sangat kontras di tengah krisis kerukunan dan toleransi di Indonesia. Bahkan, muncul istilah menarik yang digunakan oleh masyarakat sekitar untuk menggambarkan eksistensi suku Bali di Desa Patoman, yakni “Bali Van Java”. Nampaknya, istilah tersebut tidaklah terlalu berlebihan jika mengamati keberadaan suku Bali di Desa Patoman yang mampu hidup rukun dan harmonis bersama warga yang menganut agama mayoritas di sana, yakni agama Islam, serta agama-agama lainnya (Kristen dan Buddha). Hal tersebut juga dapat diamati dari berita harian "Biro Banyuwangi" tanggal 3 Maret 2016 dengan judul "Jelang Nyepi, Umat Hindu Siapkan Ogoh-Ogoh".

Dengan adanya kemultikulturan yang dimiliki oleh Desa Patoman, nampaknya angat menarik untuk dilakukan analisis terkit dengan nilai-nilai multikultural yang terkandung pada mayarakat Desa Patoman. Selain itu hal yang sanat menarik untuk dianalisis adalah bagaimana mayarakat desa Patoman mengelola kemultikulturan tersebut sehingga menimbulkan keharmonisan antar umat beragama, etnik, suku, bangsa, dan budaya.

JPSI, Vol. 2, No., 2, 2019 


\section{METODE PENULISAN}

Metode kualitatif dengan strategi studi kasus merupakan metode yang dipakai dalam penelitian ini. Latar belakang pemilihan strategi tersebut karena fenomena yang dikaji memiliki kekhususan di suatu wilayah tertentu. Oleh karena itu berdasarkan pendapat Sutopo (2006:136) maka penelitian ini tergolong dalam bidang penelitian dengan strategi kasus tunggal. Metode pengumpulan data memanfaatkan beberapa teknik, yaitu 1) Teknik observasi (observation). Peneliti memanfaatkan teknik observasi partisipasi dalam penelitian ini. Adapun objek utama yang diobservasi dalam penelitian ini adalah Desa Patoman. Secara rinci objek tersbeut terdiri dari tempat atau lingkungan sosial budaya masyarakat, benda-benda keagamaan, perilaku masyarakat dalam merawat kerukunan intern/antar umat berkeyakinan, dan persepsi generasi muda dalam mengartikan kerukunan antar umat beragama. 2) Teknik wawancara (interview). Adapun dalam penelitian ini aspek-aspek yang akan diwawancarai antara lain menyangkut latar belakang masyarakat tetap menjaga kerukunan antar umat beragama, bentuk kerukunan antar umat beragama, cara masyarakat mempertahankan kerukunan antar umat beragama dan nilai-nilai karakter yang termuat di dalam kerukunan antar umat beragama pada masyarakat majemuk di Desa Patoman. 3) Teknik Studi Dokumen. Studi dokumen yang dipakai dalam penelitian ini berupa pengambilan data yang bersumber dari arsip dan dokumen yang relevan dengan kajian ini, seperti koran, makalah, hasil penelitian, artikel, majalah, dan buku-buku yang berkaitan dengan Desa Patoman dalam bidang kerukunan antar umat beragama pada masyarakat majemuk.

Teknik penentuan narasumber dalam kajian ini yaitu purposive sampling, yakni penentuan narasumber atau sampel yang sesuai dengan tujuan peneliti (Mulyana, 2004: 187; Sugiyono, 2009: 216). Menurut Sugiyono (2009: 219) pemilihan informan dengan metode purposive sampling berdasarkan petimbangan tertentu, misalnya sosok tersebut yang dirasa paling menguasai informasi yang diharapkan, atau mungkin sosok itu adalah pejabat sehingga akan memperlancar peneliti menjelajah keadaan sosial yang dikaji. Informan dalam penelitian ini adalah orang-orang yang memiliki banyak pengetahuan tentang objek penelitian, yakni kepala desa, tetua/sesepuh desa, pemimpin keagamaan, pemimpin suku, masyarakat umum dan lain sebagainya.

Peneliti dalam penelitian kualitatif merupakan alat penelitian utama yang terlibat ke lapangan serta berupaya sendiri mengoleksi informasi melalui pengamatan, wawancara, dan telaah dokumen (Sugiyono, 2009: 222; Nasution, 1996: 54). Menetapkan fokus penelitian, memilih informan sebagai sumber data, melakukan pengumpulan data, menilai kualitas data, analisis data, menafsirkan data dan membuat kesimpulan atas temuannya adalah fungsi peneliti kualitatif sebagai human instrument (Sugiyono, 2009:

JPSI, Vol. 2, No., 2, 2019 
222). Sesuai dengan deskripsi tersebut maka dalam kajian ini peneliti merupakan instrument utama. Peneliti dalam pengumpulan data juga menggunakan beberapa instrumen penelitian antara lain: (1) pedoman observasi, (3) taperecorder, (4) buku catatan.

Data yang telah didapat diuji keabsahannya dengan menggunakan teknik triangulasi, yang terdiri dari: 1) Triangulasi sumber data dilaksanakan dengan menguji keabsahan sumber data yang diperoleh melalui telaah dokumen, wawancara, serta pengamatan. 2) Triangulasi metode dilakukan dengan pengumpulan data sejenis berdasarkan metode yang berbeda untuk kemudian dikomparasi dan disimpulkan kekuatan validitas datanya (Sutopo, 2006: 95). 3) Triangulasi teori diupayakan dengan menerapkan bentuk dan hubungan disertai analisis agar menemukan tema dan narasi pembanding (Bungin, 2009:257).

Sedangkan analisis data merupakan usaha menemukan dan menulis secara berurutan data yang didapat dari catatan lapangan, hasil wawancara, dan dokumentasi, dengan langkah mengelompokkan data ke dalam golongan, menguraikan ke dalam bagian-bagian, mengerjakan sintesa, merangkai ke dalam bentuk, menentukan mana yang utama dan yang akan dikaji, dan menarik kesimpulan (Sugiyono, 2009: 244). Teknik analisis interaktif adalah analisis yang digunakan dalam penelitian ini, yaitu semua data yang didapat dari lapangan selalu dicocokkan atau dikomparasikan dengan bagian data yang lain. Menurut Nasution (1996: 129) dalam aktivitas menganalisis data dalam penelitian kualitatif terdapat langkah-langkah umum yang harus diikuti yakni, reduksi data (data reduction), display data (data display), dan mengambil kesimpuan dan verifikasi (conclusion drawing/verifikation).

\section{HASIL DAN PEMBAHASAN}

\section{NILAI-NILAI MULTIKULTURAL MASYARAKAT DESA PATOMAN}

Karakter pada umumnya mengambarkan kepribadian yang berhubungan dengan moralitas itu, misalnya sangat tinggi atau di atas rata-rata, individu atau suatu golongan masyarakat akan tetap kuat dalam mengatasi masalah. Regenerasi yang baik tidak cukup cuma melalui keturunan, akan tetapi juga lewat pewarisan visi dan nilai. Dimana nilai dan visi yang dimaksud tentunya adalah sebuah bentuk eksistensi dari sebuah karakter yang terus diwariskan kepada anak cucu kita. Karena sebuah bangsa hanya akan bertahan melampui satu abad karena jati diri yang didukung keberlanjutan visi dan nilainya.

Karakter sebagai jati diri atau identitas bangsa adalah nilai utama kepribadian yang menjadi ladasan sistem nilai hubungan antar manusia. Berbagai karakter secara umum dirumuskan sebagai nilai hidup bersama berasaskan atas pilar kerjasama (cooperation), 
kebebasan (freedom), kasih sayang (love), toleransi (tolerance), kedamaian (peace), kejujuran (honesty), kerendahan hati (humility), tanggung jawab (responsibility), persatuan (unity), menghargai (respect), kebahagiaan (happiness), dan kesederhanaan (simplicity) (Samani dan Hariyanto 2011: 29).

Lebih jauh Lickona membagi nilai atau karakter menjadi tiga aspek, yaitu moral knowing, moral action, dan moral feeling (Lickona, 2013: 81). Moral knowing meliputi penalaran moral, pengetahuan nilai-moral, kesadaran moral, pengambilan keputusan, pengetahuan diri dan pandangan ke depan. Selanjutnya moral feeling yang meliputi rasa percaya diri, cinta kebaikan, kata hati, kerendahan hati, pengendalian diri dan empati. Langkah-langkah yang paling utama adalah moral action. Apa yang disampaikan oleh Lickona nampaknya menjadi sangat penting agar nilai atau karakter tidak stagnan pada tataran konsep semata, tetapi harus dijadikan sebagai pola dasar dalam pola piker, ucap, dan tindakan.

Berdasarkan nilai-nilai karakter yang disebutkan di atas maka nilai karakter yang dapat digali dan bersumber dari Pancasila, budaya, agama, dan tujuan pendidikan nasional meliputi nilai-nilai karakter sebagai berikut: 1) religius; 2) jujur; 3) toleransi; 4) disiplin; 5) kerja keras; 6) kreatif; 7) mandiri; 8) demokratis; 9) rasa ingin tahu; 10) semangat kebangsaan; 11) cinta tanah air; 12) menghargai prestasi; 13) bersahabat/komunikatif; 14) cinta damai; 15) gemar membaca; 16) peduli lingkungan; 17) peduli sosial; dan 18) tanggung jawab.

Berpedoman pada Nilai-nilai karakter yang telah digali di atas, maka diperlukan analisis terkait dengan nilai-nilai yang termuat dalam multikulturalisme warga di Desa Patoman, antara lain:

\section{a. Nilai Sosial}

Berdasarkan hasil penelitian masyarakat Desa Patoman menerapkan prinsip gotong royong dalam kehidupan sehari-hari mereka. Hal ini tercermin dalam beberapa aktivitas sosial seperti kerja bakti untuk membersihkan lingkungan desa, memperbaiki sarana dan prasaran publik, dan gotong royong dalam kegiatan hajatan atau perayaan hari bahagia seperti pernikahan, khitanan, pemakaman dll. Kegiatan tersebut tidak hanya dilakukan untuk sesama agama tetapi juga lintas agama dan budaya. Bagi Suku Bali menjaga keharmonisan adalah suatu kewajiban yang harus dilaksanakan berdasarkan prinsip pawongan dalam konsep Tri Hita Karana yang mengatur tentang tatacara menjalani kehidupan sosial, agama, dan berinterasi dengan alam lingkungan.

\section{b. Nilai Sosio-kultural}

Nilai-nilai sosio-kultural yang menjadi landasan kehidupan harmonis di Desa Patoman antara lain simpati, toleransi, empati, dan gotong royong. Nilai-nilai tersebut tidak hanya dipelajari dan diwariskan tapi dimanifestasikan dalam kehidupan nyata. Contoh riil 
dari penerapan prinsip ini tercermin ketika ada peristiwa meninggalnya salah satu anggota masyarakat baik beragama Islam maupun Hindu. Pada peristiwa ini setiap individu akan datang berkunjung dan membantu pemakaman jenazah. Hal ini seperti yang disampaikan oleh kepala Dusun Patoman Tengah yaitu Bapak Made dimana anggota masyarakatnya mayoritas beragama Hindu;

Ketika salah satu anggota keluarga dari warga desa yang tertimpa bencana atau wafat seringkali kami selalu bekerja sama dalam melakukan ritual penguburan jenazah, apalagi bagi umat agama Hindu ritual penguburan jenazah memang cukup kompleks sebab harus mengadakan serentetan upacara. Sekarang ini tidak hanya warga desa yang menganut Hindu saja yang berkontribusi, tetapi masyarakat dari umat beragama lain juga turut berpartisipasi atau paling tidak mengiringi sampai ke lokasi pemakaman. Hal yang sama juga dilakukan saat umat agama lain yang tertimpa cobaan, kami juga harus peduli dengan silaturahmi kerumahnya.

Relasi penuh kedamaian ini tidak hanya terjadi ketika musibah datang tetapi juga pada saat menyambut momen-momen bahagia seperti hari raya. Nuhaini (46 th) menyatakan bahwa ketika umat Hindu merayakan upacara Nyepi masyarakat agama lain juga membantu dengan cara turut serta menjaga keamanan selama pelaksanaan upacara. Seperti menjaga jalan agar tidak dilewati kendaraan agar mereka yang sedang beribadah dapat menjalankannya dengan khusyuk. Hal tersebut merupakan bentuk dari rasa empati. Johnson dkk (1983) menyatakan bahwa empati merupakan sikap dimana pelakunya memiliki kemauan untuk memahami kondisi orang lain. Sementara itu Batson dan Coke (Brigham, 1991) menyatakan bahwa empati adalah suatu kondisi dimana seseorang memiliki emosi yang dirasakan oleh orang lain. Prinsip ini dipegang teguh oleh Masyarakat Patoman dimana mereka memiliki kemauan unutk bekerjasama, saling menghormati, dan gotong-royong menciptakan kondisi yang kondusif dan aman dalam setiap perayaan keagamaan orang lain. Kesuksesan penyelenggaraan kondisi tersebut tidak lepas dari kemampuan pemimpin dalma memobilisasi masyarakatnya.

Biasanya masyarakat yang beragama Islam selalu terlibatkan dalam setiap melaksanakan kegiatan upacara agama umat Hindu yang ada di desa Patoman. Atau paling tidak tokoh masyarakat lintas agama yang tinggal di Desa Patoman akan diberitahu. Dalam kegiatan upacara Hindu, pemuda dari agama Islam juga turut membantu, misalnya untuk menjaga keamanan dan parkir kendaraan masyarakat yang menonton pawai ogohogoh ketika menjelang perayaan hari raya Nyepi pada malam pengrupukan. Selain itu, untuk wilayah Patoman Tengah ketika perayaan hari raya Nyepi, khusus jalan akan ditutup selama 24 jam dan warga beragama lain pun sangat menghargai hal ini. Sesuai dengan Johnson dkk (1983) yang mengemukakan bahwa empati ialah kebiasaan untuk mengerti situasi atau kondisi pikiran manusia lain. Sementara Batson dan Coke (Brigham, 
1991) menjelaskan empati adalah suatu kondisi emosional yang dipunyai oleh individu yang sejalan dengan apa yang dipikirkan oleh individu lain.

Warga di Desa Patoman juga mempunyai rasa empati yang besar sekali. Hal ini tampak dalam berbagai aktivitas keagamaan yang dilaksanakan baik dari warga yang beragama Hindu, Budha, Kristen, maupun Islam. Warga tetap saling membantu dalam penyelenggaraan upacara keagamaan tanpa terhalang perbedaan agama. Dengan begitu, hal tersebut membuktikan warga Desa patoman memang memiliki rasa empati yang sangat besar.

Kehidupan warga Desa Patoman selalu berkaitan dengan kebiasaan kegotongroyongan baik interetnik maupun antaretnik. Hal ini menjadi suatu kewajiban apalagi untuk keturunan Bali yang tinggal di Patoman. Ketika akan digelar upacara di pura, gotong royong bagi warga Bali yang tinggal di Patoman tampak sangat nyata. Biasanya orang-orang Bali akan menyiapkan rentetan upacara yang akan digelar dengan gotong royong. Selain itu juga, ketika perayaan hari raya Nyepi, gotong royong sangat dibutuhkan misalnya selama pembuatan ogoh-ogoh maupun dan mengiring ogoh-ogoh.

Desa Patoman dalam melakukan gotong royong dapat dikatakan mempunyai kekhasan tersendiri, yaitu gotong royong dilaksanakan oleh seluruh entik mulai interetnik sampai antaretnik. Hal ini dikemukakan oleh Bapak Made Swastika sebagai tokoh masyarakat yang menyampaikan bahwa "Warga dan pemuda etnik lain selalu membantu proses upacara yang akan kami laksanakan. Selain ikut membantu menjaga keamanan, mereka juga biasanya ikut mengamankan parkir kendaraan."

\section{c. Nilai Religius}

Di Desa Patoman, nilai religius yang hidup dalam masyarakat multikultur ditandai dengan adanya beberapa rumah ibadah dari beberapa agama yang tinggal di desa tersebut. Misalnya musala, masjid, dan pura. Setiap pemeluk agama bisa menjalankan ajaran dan agama yang dianutnya dengan bebas dalam pelaksanaan sehari-hari. Hal ini selaras dengan perwujudan Pancasila sila pertama yaitu Ketuhanan Yang Maha Esa.

Pura memiliki peran yang sangat penting dalam menjaga harmonisasi kehidupan warga Bali yang tinggal di Desa Patoman selain memiliki fungsi social, pura juga memiliki nilai religious dalam menjaga kedamaian interaksi antara manusia dengan Sang Penciptanya. Terkait dengan keberadaan pura yang ada di Desa Patoman dapat dilihat pada gambar berikut. Meskipun mayoritas penduduk di Desa Patoman memeluk Islam yang juga mendirikan banyak musala dan masjid yang tersebar di berbagai sudut desa, pura juga berdiri dengan aman dan bebas. Walaupun masyarakat yang beragama Islam sebagai kelompok mayoritas, mereka juga menjamin keleluasaan umat agama lain. Sifat religius dari warga yang beragama Islam ditunjukkan dengan keberadaan masjid dan musala ini. Selain digunakan sebagai sebagai tempat ibadah sehari-hari, keberadaan masjid JPSI, Vol. 2, No., 2, 2019 
juga dijadikan sebagai wadah untuk melaksanakan beberapa aktivitas keagamaan seperti pengajian dan pendidikan Alquran bagi generasi muda di lingkungan Desa Patoman.

\section{d. Nasionalisme}

Masyarakat multikultur di Desa Patoman pada umumnya juga memiliki sikap nasionalisme. Sikap ini tercermin dalam kemauan masyarakat lintas agama untuk saling bekerjasama dalam membangun desa misalnya ketika diadakan kerjabakti, bersih desa, persiapan perayaan hari kemerdekaan dll. Semarak nasionalisme yang paling terasa ketika menjelang perayaan kemerdekaan Indonesia. Selain pemasangan berbagai atribut seperti bendera, umbul-umbul, dan hiasan jalan. Masyarakat juga bekerjasama unutk menyelenggarakan berbagai perlombaan anak-anak hingga dewasa untuk memeriahkan peringatan hari ulang tahun bangsa Indonesia. Dilihat dari keberagaman yang ada tidak salah jika kita menganggap Patoman adalah gambaran mikro dari NKRI.

\section{e. Gotong Royong}

Kegiatan gotong royong baik interetnik maupun antaretnik telah menjadi bagian yang menyatu dalam kehidupan warga Desa Patoman. Bagi orang-orang Bali yang hidup di Patoman, hal ini menjadi suatu kewajiban. Gotong royong dalam warga Bali yang tingga di Patoman terllhat sangat nyata ketikan akan menyelenggarakan upacara di pura. Biasanya dalam menyiapkan rangkaian upacara yang akan digelar, orang-orang Bali akan gotong royong. Selain itu juga, pada saat perayaan hari raya nyepi, gotong royong seringkali dilaksanakan. Khususnya dalam perakitan ogoh-ogoh dan membawa ogoh-ogoh.

Sejalan dengan yang disampaikan Made Widado menjelaskan bahwa "dalam proses pembuatan ogoh-ogoh membutuhkan biaya yang cukup banyak. Maka dari itu diperlukan urunan dari krama banjar". Hal ini menunjukkan sikap kegotong royongan msayakat Bali yang ada di Desa Patoman sangat tinggi. Lebih lanjut diungkapkan bahwa dalam pelaksanaan upacara kegamaanpun selalu berdasarkan asas kegotong royongan mulai dari perlengkapan sarana dan prasarana upacara juga dibebankan kepada warga ada yang membawa kelapa, janur, gula, beras, daun pisang, dan lain sebagainya yang dibutuhkan untuk kelengkapan upacara.

\section{f. Demokrasi}

Nilai Demokrasi tergambar dalam kehidupan masyarakat Desa Patoman adalah pada saat ajang pilkades, pileg, dan pilpres. Hal ini tercermin dari tingkat partisipasi pemilih dalam setiap even pemilu. Selain itu juga demokrasi tidak hanya terjadi dalam tatanan kehidupan politik tetapi dalam kehidupan sosial dan budaya juga lebih menekankan kepada proses demokrasi. Cerminan sikap dekorasi ini juga terwujud dalam penyelesaian masalah-masalah sosial seperti pertengkaran antar kelompok dll. Selain itu juga terdapat diskusi lintas etnik dan agama untuk menjaga kehidupan damai antar kelompok. 


\section{g. Bersahabat/Komunikatif}

Nilai bersahabat atau komunikatif antaretnik yang ada di Desa Patoman sangatlah harmonis. Hal ini bisa dilihat dari ada atau tidaknya konflik yang terjadi antaretnik yang ada. Berdasarkan apa yang disampaiakan bapak Nuhaini (46 Tahun) mengatakan sebagai bahwa "dalam beberapa tahun di Desa Patoman Belum ada konflik yang terjadi antaretnik yang ada. Baik itu dari golongan pemuda maupun dari kalangan orang tua".

Adanya komunikasi antaretnik memang sangat diperlukan dalam masyarakat yang multikultur dalam kaitannya untuk menjaga kerukunan antar etnik yang ada. Kemultikulturan yang ada dalam masyarakat Patoman harus dipandang sebagai suatu kelibhan yang harus dijaga dan dilesatrikan bukan sebuah kekurangan sehingga harus diseragamkan. Adanya komitmen bersama untuk menjalin komunikasi yang intensif dalam menjaga keberagaman patut diapresiasi dan dicontoh oleh daerah-daerah lain yang memiliki kultur yang beragam. Dalam menjaga keberagaman ini tidak hanya menjadi tanggungjawab aparatur desa tetapi sudah menjadi tanggungjawab seluruh warga desa Patoman.

\section{h. Peduli Lingkungan}

Lingkungan merupakan salah satu komponen yang harus dilestarikan agar dapat memberikan manfaat yang lebih bagi masyarakat. Dilihat dari keadaan alamnya Desa Patoman memiliki alam yang beriklim sedang yang sebagian besar wilayahnya berupa lahan perkebunan dan pertanian. Desa patoman juga memiliki garis pantai yang sangat potensial untuk dikembangkan menjadi daya Tarik objek pariwisata.

Dalam menjaga lingkungan selain memang ada himbauan dari aparatur desa tetapi juga karena memang kebiasaan masyarakat di sini memang senantiasa menjaga lingkungan alam tertama adalah daerah perkebunan dan daerah pesisir. Khusus untuk daerah pesisir mendapat perhatian khusus karena dekat dengan pantai sehingga seringkali terjadi abrasi.

Masyarakat Bali yang ada di Desa Patoman juga mempunyai kearifan lokal dalam hubungannya dalam menjaga lingkungan yang memang mengharuskan mereka untuk menjaga lingkungan. Hal ini sesuai dengan penjelasan yang diutarakan oleh Bapak Made Swastika sebagai berikut.

Sudah menjadi keharus warga Bali yang ada di Patoman ini untuk merawat hubungan yang terpuji dengan alam lingkungan tanpa harus ada himbauan dari siapapun. Hal ini karena kami selalu berpedoman pada ajaran Tri Hita Karana. Dimana salah satu ajaran dalam kearifan lokal tersebut diharuskan untuk melestarikan hubungan yang harmoni antara alam lingkungan dengan manusia. Di samping juga harus menjaga hubungan yang harmoni antara manusia dengan sesama manusia, dan manusia dengan Tuhan Yang Maha pencipta. 
Konsep Tri Hita Karana yang tersusun dari Parahyangan, Pawongan, Palemahan (Suparman, 2003 : 133; Widana, 2006:53; Pitana, 1994 : 148; Santeri, 2005 : 84). Tri Hita Karana secara etimologi merupakan tiga unsur sumber kebahagian yang memberi pesan tentang keserasian, keselarasan dan keseimbangan (Manuaba, 1999: 61; Sudibia, 1994: 98). Jadi Tri Hita Karana bisa dimaknai sebagai tiga hubungan damai yang memuat filsafat keselarasan, keserasian dan keseimbangan yaitu hubungan antara individu dengan Tuhan, individu dengan sesama individu dan individu dengan alam lingkungannya (Atmadja, 2006: 17; Kerepun, 2005:62; Nida, 2004: 53, Partia, 1996: 7; Putra, 2003: 119; Santeri, 2000: 115). Unsur palemahan menjadi unsur yang sangat vital untuk menjaga lingkungan.

\section{MENGELOLA KEMULTIKULTURAN DI DESA PATOMAN, BLIMBINGSARI, BANYUWANGI}

\section{a. Dialog dan Kerjasama antarumat Beragama}

Kehidupan kepercayaan dan beragama kepada Tuhan Yang Maha Esa semakin tumbuh sehingga terpupuk hidup kerjasama dan rukun bagi semua penganut agama dan pemeluk aliran kepercayaan kepada Tuhan Yang Maha Esa. Kerjasama ini akan memperkuat kesatuan dan persatuan negara dan bangsa. Di dalam hubungan kerjasama sejalan dengan nilai-nilai dan norma yang termuat dan tersirat di dalam Pancasila, khususnya sila Ketuhanan Yang Maha Esa, yaitu kerja sama yang dilandasi:

a. Toleransi hidup beragama, keyakinannya dan kepercayaannya masing-masing.

b. Menghormati manusia yang sedang melakukan ibadah.

c. Tolong menolong dan bekerja sama tanpa memandang perbedaan agama.

d. Tidak memaksakan kepercayaan dan agamanya kepada manusialain.

Kerja sama antarumat beragama adalah bagian dari interaksi sosial antar manusia yang bukan perbuatan dosa bagi semua ajaran agama yang hidup di Desa Patoman. Hubungan dan kerja sama dalam aspek ekonomi, aspek politik, maupun aspek budaya tidak dilarang, bahkan disarankan selama berada dalam ranah lingkup kebaikan dan saling menguntungkan antar sesama. Dari perspektif tersebut, masyarakat Desa Patoman “...sebagai umat manusia yang memeluk agama yang berbeda mampu menjalin suatu kerjasama yang baik bagi masyakarat, negara dan bangsa" seperti yang diungkapkan oleh Made Widado (45 tahun) (Hasil wawancara tanggal 10 Juli 2019).

Kerja sama di kalangan pemeluk agama adalah bagian yang sangat utama dalam kehidupan bermasyarakat di Desa Patoman. Kehidupan dalam masyarakat akan menjadi tertib, damai, aman, dan tentram dengan kerjasama yang erat di antara mereka. Aksi kerja sama antar umat beragama di Desa patoman di antaranya adalah sebagai berikut: 
a. Adanya dialog antar pemimpin agama ketika akan menyelesaikan suatu permasalahan ataupun ketika pemerintahan desa akan merumuskan suatu kebijakan yang berdampak pada eksistensi pemeluk agama-agama yang ada di Desa Patoman.

b. Adanya kesepakatan di antara pemimpin adat, tokoh masyarakat masing-masing dalam menjaga keberagaman di Banyuwangi. Dialog kesepakatan ini dapat diketahui dengan adanya tokoh-tokoh masyarakat di Desa Patoman yang menjadi bagian dari Forum Pembauran Kebangsaan (FPK) Kabupaten Banyuwangi. Sedangkan dalam menjaga keberagaman agama di Banyuwangi dan khususnya

c. Saling menyumbangkan bantuan jika mengalami musibah, bencana alam ataupun bergotong-royong ketika masyarakat Desa Patoman akan melaksanakan bhakti sosial di sekitar wilayah Desa. Bentuk kerjasama ini dilakukan oleh seluruh masyarakat desa tanpa memandang identitas agama ataupun kesukuannya.

Setiap umat beragama di Desa Patoman diharapkan selalu memupuk kerukunan dan kerja sama antar umat beragama. Dialog antar-umat beragama adalah salah satu cara menjadikan agama sebagai faktor pemersatu dalam kehidupan berbangsa dan untuk memperkokoh kerukunan beragama. Para tokoh dan umat beragama bisa berkolaborasi dan bersinergi untuk menggalang kekuatan bersama guna mengatasi berbagai masalah sosial termasuk kemiskinan dan kebodohan serta aktif berpartisipasi dengan berdialog secara terbuka.

\section{b. Meyakini Agama Sendiri dan Menghargai Agama Orang Lain}

Kehidupan masyarakat di Desa Patoman nampak sangat damai dan rukun walaupun didasari oleh perbedaan agama dan suku. Rumah ibadah antara agama Islam dan Hindu memiliki posisi tempat peribadatan yang saling berdampingan secara harmonis juga merupakan suatu realitas sosial yang sangat menarik di tengah krisis kerukunan dan toleransi di Indonesia. Hal ini menunujukkan toleransi yang sangat tinggi sehingga melahirkan julukan "Bali Van Java" untuk menggambarkan eksistensi suku Bali di Desa Patoman. Keberadaan pemeluk agama Hindu di Desa Patoman memiliki makna adanya kebebasan dalam memeluk maupun mengimplementasikan ajaran-ajaran agama ataupun tradisi agama tanpa adanya gangguan atau larangan dari pemeluk agama lainnya. Hal ini terlihat jelas pada saat pelaksanaan Hari Raya Nyepi di Desa Patoman, dimana Pecalang dan Banser bahu-membahu mengamankan perayaan Nyepi tahun saka 1939. Secara berkelompok, mereka terlihat berkeliling di Banjar Dusun Patoman Tengah. Mereka menyaksikan kondisi umat Hindu yang sedang melakukan tapa brata penyepian. Mereka juga aktif menegur sopir material yang melintas supaya ikut menjaga ketenangan. Mereka memantau suasana saat perayaan Nyepi tetap kondusif dan tenang. Kehadiran pengamanan dari pasukan Banser NU berperan aktif pada peringatan nyepi saja dan ketika perayaan tawur agung kesanga serta JPSI, Vol. 2, No., 2, 2019 
kirab ogoh-ogoh. Pasukan Banser NU juga ikut membantu dengan menertibkan pengendara sepanjang rute kirab ogoh-ogoh.

Sejak puluhan tahun lalu keadaan kerukunan antar umat beragama di Banjar Patoman tengah, Desa Patoman sudah berlangsung. Mereka mengaku tak pernah bertengkar paham lantaran antar umat beragama di wilayah ini sudah hidup rukun dan damai, meskipun berbeda ras, suku dan agama. "Tidak pernah ada selisih di kalangan kami dan rasa kekeluargaan sudah terjalin cukup lama di antara kami," cetusnya. Sementara Mashud, Komandan Satkorcab Banser NU Banyuwangi, mengatakan, pengamanan yang dilaksanakan Banser NU tersebut merupakan menjaga kebersamaan dalam bagian pluralisme di tengah multikulturalisme guna melestarikan kerukunan antar umat beragama.

\section{c. Doa Bersama}

Doa bersama adalah salah satu wadah budaya yang bisa mendukung kerukunan antarumat beragama (Sumbulah dan Nurjanah, 2013: 155). Hal ini biasanya dilihat pada saat pada saat ada kegiatan-kegiatan yang bersifat formal ataupun nonformal (rapat desa, sosialisasi desa, bhakti sosial) yang diselenggarakan oleh pemerintahan desa pasti diawali dengan dosa bersama menurut agama dan kepercayaan masing-masing masyarakat Desa Patoman. Menurut Made Widado (40 Tahun), “...meski kepercayaan dan cara berbeda-beda, tetapi yang disembah tetap satu, yaitu Tuhan Yang Maha Esa, sebagaimana yang termuat dalam dasar negara Indonesia". Bagi masyarakat Desa Patoman, Pancasila merupakan landasan yang paling penting dalam mewujudkan masyarakat yang toleran, rukun, dan harmonis antar agama maupun suku yang berbeda-beda.

\section{d. Komunikasi Lintas Budaya}

Komunikasi lintas budaya menurut Samovar, Porter \& McDaniel (2010) terjadi saat anggota dari satu budaya tertentu menyampaikan pesan kepada anggota dari budaya yang lain. Lebih tepatnya, komunikasi antarbudaya menarik hubungan antara orangorang yang sistem simbolnya dan persepsi budaya cukup berbeda dalam suatu komunikasi. Singkatnya komunikasi antarbudaya atau lintas budaya adalah komunikasi yang terjadi antar orang atau kelompok dari budaya yang berbeda.

\section{e. Toleransi, Simpati, dan Empati}

Sikap masyarakat Desa Patoman yang memiliki nilai simpati tercermin ketika ada warga yang ada anggota keluarganya yang meninggal atau tertimpa musibah baik yang beragama Hindu atau Islam, maupun yang lainnya. Biasanya masyarakat akan bersilaturahmi ke rumah duka dan menyampaikan bela sungkawa kepada keluarga yang ditinggalkan. 
Lebih lanjut Bapak Nuhaini (46 Tahun) menyatakan bahwa "warga kami sudah saling menghormati satu sama lain dalam kehidupan sehari-hari. Kami juga menghormati hari raya Nyepi ketika umat hindu melaksanakan upacara nyepi. Bahkan kami menjamin kelancaran hari raya nyepi tersebut dengan mengawasi jalan yang ada di lingkungan umat Hindu agar tidak dilewati kendaraan agar saudara yang merayakan Nyepi bisa tenang menunaikan ibadahnya." Deskripsi tersebut di atas jelas membuktikan bahwa masyarakat Desa Patoman tidak melihat status agama apa pun dalam menjalin kerukunan dan hidup saling menghormati antara agama. Perilaku ini akan menghasilkan kedamaian dalam kehidupan masyarakat Desa Patoman.

Warga di Desa Patoman juga mempunyai rasa empati yang sangat besar. Hal ini tampak dari berbagai aktivitas keagamaan yang dilakukan baik dari warga yang beragama Hindu, Islam, Kristen, maupun Buddha. Hal ini sejalan dengan apa yang dikemukakan oleh Bapak Suwito selaku kepala Desa Patoman bahwa:

Rasa empati masyarakat saya bisa dikatakan sangat besar mengingat bahwa warga di sini sangat majemuk. Perbedaan agama, ras, etnik, budaya, dan suku bukanlah rintangan dalam membina kerukunan di Desa Patoman. Misalnya ketika warga yang beragama Islam mengadakan kegiatan ritual keagamaan maka warga yang beragama Hindu juga ikut membantu dalam ritual tersebut. Begitu juga sebaliknya jika warga yang beragama Hindu sedang upacara maka masyarakat yang bergama Islam juga ikut berkontribusi dalam mensukseskan upacara tersebut.

Kesaksian bapak kepala desa tersebut menunjukkan bahwa keberagaman yang melekat di Desa Patoman tidak menjadi ganjalan bagi warga untuk saling membantu dalam penyelenggaraan ritual keagamaan. Rasa empati yang sangat tinggi dengan demikian tampak nyata di antara warga Desa Patoman. Kesaksianitu juga disepakati oleh bapak Made Swastika sebagai tokoh masyarakat dari kalangan Hindu yang menyatakan sebagai berikut.

Dalam setiap melaksanakan biasanya masyarakat yang beragama Islam selalu dilibuatkan dalam kegiatan upacara agama umat Hindu yang ada di desa Patoman. Atau paling tidak kami mengabarkan kepada tokoh masyarakat lintas agama yang tinggal di Desa Patoman. Selain itu, dalam kegiatan upacara juga kami lakukan, para pemuda dari agama Islam juga turut terlibat. Contohnya ketika mendekati perayaan hari raya Nyepi pada malam pengrupukan, mereka mengawasi ketertiban dan parkir kendaraan warga yang menyaksikan pawai ogoh-ogoh.

JPSI, Vol. 2, No., 2, 2019 


\section{SIMPULAN}

Desa Patoman merupakan desa dengan tingkat kemultikulturan yang tinggi. Mulai dari agama Islam dengan jumlah $82.3 \%$, Hindu mencapai $17.3 \%$, Kristen sebanyak 8 jiwa, Buddha 7 Jiwa dan kepercayaan khususnya kejawen. Dilihat dari etnik seperti Madura, Jawa, Bali, dan Osing. Dalam menjaga dan menelola kemultikulturan Desa Patoman dapat dijadikan sebagai rujukan untuk desa-desa lain yang ada di Banyuwangi khususnya dan Indonesia pada umumnya.

Berdasarkan analisis yang sudah dilakukan terhadapat kehidupan sosial, budaya, dan lingkungan masyarakat Desa Patoman dapat diambil beberapa nilai-nilai kemultikulturan, yaitu nilai Sosial, Sosio-kultural, Religius, Nasionalisme, Gotong Royong, Demokrasi, Bersahabat/Komunikatif, Peduli Lingkungan.

Menjaga dan mengelola kemultikulturan bukanlah sesuatu yang mudah diperlukan kerjasama antar maupun inter komponen seluruh lapisan masyarakat. Elain itu juga diperlukan sinergi antara masyarakat, tokoh agama, tokoh adat, budaya, etnik, suku, ras dan bangsa dengan pemerintah baik desa, daerah, dan pusat. Dalam mengelola kemultikulturan yang ada di Desa Patoman dilakukan melalui beberapa cara, yaitu Dialog dan Kerjasama antarumat Beragama, Doa Bersama, Komunikasi Lintas Budaya, Meyakini Agama Sendiri dan Menghargai Agama Orang Lain, Toleransi, Simpati, dan Empati, Desa Kebangsaan, Forum Pembauran Kebangsaan, dan Forum Kerukunan Antar Umat Beragama.

\section{DAFTAR PUSTAKA}

Atmadja, N.B. 2010. Ajeg Bali: Gerakan, Identitas Kultural, dan Globalisasi. Yogyakarta: LKiS

Atmadja, N.B.. 2006. "Kearifan Lokal dan Agama Pasar", dalam Media Komunikasi Sejarah Lokal Candra Sangkala Bali dalam Perspektif. Edisi Khusus Diterbitkan dalam Rangka Purnabakti Drs. Made Sunada. IKIP Negeri Singaraja

Bungin, H. M. 2009. Penelitian Kualitatif: Komunikasi, Ekonomi, Kebijakan Publik, dan IImu Sosial Lainnya. Jakarta: Kencana Prenada Media Group

Kerepun, M. K. 2005. "Analisis S.W.O.T dalam Strategi Mencapai dan Memelihara Ajeg Bali", dalam Dialog Ajeg Bali: Perspektif Pengalaman Agama Hindu (Penyunting: Titib). Surabaya: Paramita

Lickona, T. 2013. Educating for Character: How Our Schols Can Teach Respect and Responsibility: Mendidik Untuk Membentuk Karakter: Bagaimana Sekolah Dapat 
Mengajarkan Sikap Hormat dan Tanggung Jawab. (Penerjemah: Juma Abdul Wamaungo, Ed. Uyu Wahyudi dan Suryani). Jakarta: Bumi Aksara

Manuaba, A. dkk. 1999. Bali Dan Masa Depannya. Wayan Suparta (editor). Denpasar: PT BP

Mulyana, D. 2004. Metodologi Penelitian Kualitatif: Paradigma Baru Ilmu Komunikasi dan IImu SosialLainnya. Bandung: PT Remaja Rosdakarya

Nasution, S. 1996. Metode Penelitian Naturalistik-Kualitatif. Bandung: Tarsito

Nida, Diartha. 2004. Sinkretisasi Siwa-Buddha di Bali : Kajian Historis Sosiologi. Denpasar: $\mathrm{BP}$

Partia, I G. R. 1996. Menyorot Aneka Masalah Umat Hindu. Denpasar: Yayasan Dharma Naradha

Pitana, I G. 1994. "Desa Adat dalam Arus Modernisasi”, dalam Dinamika Masyarakat dan Kebudayaan Bali ( Editor: Pitana). Denpasar : Bali

Putra, I M. A. 2003. "Tri Hita Karana di Antara Teori dan Aplikasi", dalam Perempatan Agung : Menguak Konsepsi Palemahan Ruang dan Waktu Masyarakat Bali (Editor: Jiwa Atmaja). Denpasar : CV Bali Media Adhikarsa.

Santeri, R. 2000. Tuhan dan Berhala: Sebuah Perjalanan dalam Hindu. Denpasar: Yayasan Dharma Naradha.

Santeri, R. 2005. "Struktur Sosial Masyarakat Bali", dalam Kasta dalam Hindu Kesalahpahaman Berabad-abad (Penyunting : Putu Setia). Denpasar : Yayasan Dharma Naradha.

Sudibya, I G. 1994. Hindu : Menjawab Dinamika Zaman. Denpasar: BP

Sugiyono. 2009. Metode Penelitian Kuantitatif, Kualitatif dan R\&D. Bandung: CV. Alfabeta

Suparman. 2003. "Tri Hita Karana Sebagai Landasan Hidup Masyarakat Bali", dalam Perempatan Agung : Menguak Konsepsi Palemahan, Ruang dan Waktu Masyarakat Bali (Editor: Jiwa Atmaja). Denpasar : CV. Bali Media Adhikarsa

Sutopo, H. B. 2006. Penelitian Kualitatif: Dasar Teori dan terapannya Dalam Penelitian. Surakarta: Universitas Sebelas Maret

Widana, M. 2006. Upacara Mulang Pakelem di Danau Segara Anak Gunung Rinjani Lombok. Surabaya: Paramitha. 